\title{
Study on the Construction of Pluralistic Practice Teaching System in Innovative Logistics Information Talents
}

\author{
Zhou Li , Zhu Jie \\ School of Information \\ Beijing Wuzi University \\ Beijing, China \\ Zhoulibit@126.com; Zhujie@bwu.edu.cn
}

Keywords: pluralistic teaching, innovative teaching, logistics information talents

\begin{abstract}
Diversified practice teaching system is an important way to enhance students' practical skills and social adaptability. In this paper, the system is built to cultivate innovative talents of logistics information industry for logistics development through integrating the core ideas and methods in the field of logistics, developing production-teaching-research combination teaching mode, reforming teaching forms such as adding Mooc and micro class, forming a team of outstanding teachers, etc.
\end{abstract}

\section{Introduction}

Under the social development of Beijing-Tianjin-Hebei integration process, with the construction goal of being a high-level characteristic university, our school explores the educational mode of service regional innovative personnel training actively on the basis of the logistics industry, its own characteristics and the local reality. We strive to construct a diversified practice teaching system, form the talent-cultivating concept for industrial applications and train innovative talents of logistics information, combined with the new situation of logistics internationalization, informationization and lean triggered by the global economic and technological development. The building of a pluralistic practice teaching system is researched by integrating the core idea and technology in the field of logistics information such as logistics information technology, networking technology, the lean logistics technology, etc. To change the traditional pattern of single subject construction and expand the extension of the traditional teaching, we introduce a large number of equipment, technologies and information resources widely in various forms into diversified teaching through school-enterprise cooperation and cooperation with the government, encourage teachers to participate in corporate research projects, students to participate in scientific research projects of the teachers and students to participate in independent innovative projects, and we study the development of university-industry-research combination mode further, carry out the practice teaching quality research, construct the core quality curriculum, encourage reform of Mooc and micro class forms, and organize a team of outstanding teachers.

Theoretical significance of the research project: adapt to the need of training professional talents of logistics information and research improving the quality of talent training comprehensively, explore the talent training pattern, and construct a training system of innovative practice ability .Practical significance: (1) to provide students with the most modern and intelligent innovation practice platform. (2) the faculty building channels have been greatly expanded, and the good guarantee of teaching work have been formed. (3) Customizing training systems according to enterprise and social demands, introducing the interns' mechanism and forming the excellent circulation of university-industry-research combination system. (4) Transporting innovation and 
technical personnel to logistics information industry for the cultivation concept of industrial applications practice.

\section{The construction objective of pluralistic practice teaching system}

\section{Comprehensive goals}

Through systematic training, we expect to enable students to have good practical concept, practical spirit and practice ability, and through mobilizing the students' enthusiasm fully, giving play to the role of self-management and innovation of practice teaching operation and management mechanism in the practice of the teaching process, we intend to cultivate students' innovative thinking, innovative spirit and innovation ability.

\section{Specific objectives}

(1) To build practice teaching system of logistics informatization talents training. In order to achieve this goal, we must survey social skills demand for logistics information technology professionals extensively based on logistics and information, analyze general and specialized skills which logistics information technology professionals should possess, and then clear the practice teaching needs of logistics informatization talents training. We should also construct practical logistics information personnel training practice teaching system, combined training programs and teaching arrangements of seven professional in Information Institute and coordinated to match the practical teaching content, time, form, progress and other aspects.

(2) To promote the depth of integration of information technology and education, and explore the innovation using of micro lesson in the classroom. To accomplish this objective, we plan to pick out fundamental knowledge suitable for micro course reform in the logistics information course and select teachers who can be recorded micro class to record 10-20 minutes of video about the related knowledge points, which is going to be used in teaching and summarized experience by divided into three phases.

(3)To research building programs of teaching and training courses adapting for logistics IT training objectives. Through in-depth research social needs the actual business case is introduced into courses, practical course reform and teaching reform is conducted, and multi-level threedimensional practice teaching system is constructed.

(4)To achieve the management of undergraduate research process with "Big Year Project" and "discipline competition" for the lead. It aims to promote innovation and entrepreneurship training model of reform, to strengthen students ' innovative entrepreneurship training, and to enhance the students' creative ability and entrepreneurship.

\section{The construction of pluralistic practice teaching system}

Constructing Pluralistic Practice Teaching System from curriculum practices, special practices, projects and academic competitions and other aspects of practice

Students verify, simulate and design basic theory knowledge according to the experiment content assigned by the teacher, while teachers mainly adopt situational teaching environment simulation, and practice of the course is mainly implemented in the laboratory.

Special practice mainly reforms to adopting the way of curriculum design, curriculum practice and internship and allowing students to compare the systematic, complete and strong-sensitivity practice in the concentration of time.

Project practice is mainly conducted in students' spare time or holiday, and in the practice, students participate in the college students' innovative entrepreneurial projects, open experiment and teachers' transverse, longitudinal research topic organized by the school and the full-time teachers as a guide, and do a real project during the university to lay a foundation of future professional roles as soon.

Discipline competition is designed to allow students to participate in the discipline, skills competitions organized by school Dean and College, and even to participate in the province and the 
country's high level of competition through layers of selection. Isa promote learning, means to be enable students to see competition as a means of learning, develop their sense of competition and team spirit.

Practice teaching is the link between classroom teaching and social life, is an important means of cultivating students' professional ability and professional quality, and is an important part of the applied talents training.

The goal that we construct a diversified practice teaching system is to mainly improve the students' ability of studying independently as well as observation, analysis, problem solving skills. We adopt the experimental teaching mode aimed for practice innovation to pay attention to engineering practice and innovation ability training, so as to make students meet the needs of modern engineering technology innovation ability, organization and coordination ability, management ability, and the corresponding character and good qualities on the basis of the master professional knowledge to lay a good foundation for future practice and employment.

According to the cognitive level of students from different grades, characteristics of social experience and arrangements of the professional training program curriculum and different courses, different expertise and different teaching stages, the practice teaching design research is carried out and a diversified teaching system is built accessorily to form the theoretical and practical teaching benign interaction, by integrating internal and external resources effectively in the open concept and using campus laboratory teaching, simulation teaching and case teaching, school practice teaching base, internships, summer social practice, business practice and other forms.

Building a diversified training class curriculum system of "professional + more course + multilevel + requirements"

The training course is very important in the undergraduate curriculum system, because it is a kind of educational philosophy, but also a means of education and links. Diversity training curriculum system refers to guiding students to develop character and train the ability of knowledge application, information-access, message selecting, practice and application to improve the overall quality of students without consuming more of the conditions of teaching resources. Therefore, it is necessary to implement diversity training class curriculum system in higher education teaching.

Main contents about building a diversified training curriculum system include:

(1) Optimizing the structure of training curriculum system

The content mainly refers to increasing the proportion of training course, strengthening practical ability training of professional talents in the field of logistics information, especially computer science and technology, the Internet of things engineering, information engineering, information management, e-commerce and other undergraduate talents training.

(2) Prominent platform, modular design

To construct the diversified training class curriculum system, we need to focus on platform building and modular design, form teaching framework which meets multi-disciplinary and multilevel demand, integrates curriculum group construction, and realize the requirement of diversify abilities training, on the basis of original content system of" professional + more course + multi-level + requirements".

Platform building consisted of training courses system includes intelligent logistics multidisciplinary basic experiment platform based on the basic discipline of Logistics experimental training requirements, professional comprehensive ability training test platform focusing on professional capacity building, innovative ability experimental platform whose purpose is to train creative ability according to disciplinary basic research platform, and off-campus practice experiment platform which realizes the application and practice of theoretical knowledge and encourages students to further innovation to test the students' learning effect on the basis of the campus practice base and through building school-enterprise cooperation laboratory.

These four platform construction helps enhancing the students' practical ability successively, and comprises a four level experimental teaching system, so as to realize the need of training logistics information professionals who possess thick foundation, wide caliber, practical and strong abilities and are high-quality compound talents, and form a diversified training class curriculum teaching training mode. 


\section{Construction of competitive logistics information series practical courses and materials}

Build practical courses of logistics information and publish textbooks and monographs for training. In addition, high-level papers of teaching reform should be written.

Competitive practical courses of logistics information are constructed. Logistic information courses include: training for company's resource planning, analysis and design for e-commerce system, Statistical Product and Service Solutions (SPSS), Statistical Analysis System (SAS), technology of Internet of Things, Data Mining, application design and exploitation of Internet of Things, training for logistics information technology, training for system modeling and simulation, mobile application development training, intelligent logistics systems, e-commerce and logistics, cloud computing, image processing and recognition technology, artificial intelligence and so on. Logistics Information courses are constructed based on department and specialty and innovation base of practice in campus, and the implementation of college project as well as course leader responsibility system, which course director in charge of the development organization and implementation of quality curriculum-building programs. Around the college's professional development plan that features logistic information, the training quality of innovative applied talents is promoted constantly with the help of teaching staff building by high-quality courses, and the process and reform of teaching method.

Teaching materials of practical training, monographs and papers of logistics information. Teaching materials of practical training and monographs are the direct reflection of teacher's practical teaching effect, as well as summary of practice experience of designing course' structure and contents when teachers devote themselves to the practical courses by combining practical training and theoretical knowledge. Creating multiple practice teaching system and training innovative logistics information talents is an indispensable step in teaching materials construction. Top-quality teaching materials that suit for the need of talent cultivation are made by encouraging teachers to transform their own scientific research achievements into practical teaching cases, introducing external teachers to upgrade curriculum resources and reflecting the constant renewal in the curriculum content. In the teaching process, teachers will also accumulate teaching experience and regularity and publish high-level teaching papers.

\section{Reformation and innovation research for micro courses of logistics information}

Lead teachers to conduct the reformation of micro logistics courses teaching by recording a short video about part of the knowledge points for 10 to 20 minutes, which is used before class or in class in order to share resources of high quality courses. Lead teachers to pay more attention to the teaching and learning process and method improvement. A variety of teaching methods such as "flip class" are used to deep the integration of teach method and modern technology with the help of new technologies. Moreover, the focus point is made a transition from to teaching to learning, while the act point is under the development of students and the experience of learning process.

Entrepreneurship program for students and competitions of subjects are used to promote the practical construction of specialty

Rules and regulations for students' innovation activities in technology are set up in order to encourage teachers and students to participate in entrepreneurship program and competitions. It could promote the professional teaching reform as well as strengthen the comprehensive training courses that embody practicability and technicality. Searching for competition projects from engineering practices would guide the direction of student employment. Improve the mechanism and system further and increase investment, standardize management as well as pay attention to monitoring. Solid progress would be made in project construction for the sake of producing atmosphere that"learn by doing, thinking in study, create when thinking" 


\section{Key features}

A practice training program of teaching for students named "foundation + application + integration" is constructed under the guidance of the teaching thought of innovation; A teachers team is built contains different classes divided by age. And a strategy of team building is formed, that is, young, middle-aged and old group keep pace with others. Meanwhile, we carry out teaching reform and innovation of research of the fine-designed logistics information courses, and create a series of excellent courses and teaching materials; Large projects and competitions are prepared for the promotion of subject construction and students' practical ability training; Teachers guide students to participate in research projects as the sake of the integration of production, education and research.

For freshmen and sophomores, there is a training system of practical knowledge at elementary stage called"zero base, universal coverage" will be built. It includes practice of innovation thinking and trainings of science and engineering competitions. The object is to fill in the practical blanks for junior students.

For sophomores and senior students a training system of practice with an emphasis on application and operation is carried out at application period. It contains the college students' scientific research project of primary cultivation, innovation methods application practice, comprehensive experimental training and professional practice training.

For junior and senior student, a practical ability training system aimed "strengths enhancement and jobs encouragement" is built at improvement period, which including professional competition of science and technology, international exchanges of visits, senior college students' scientific research project training, he practical project, the innovation practice internship, etc.

A diversified training courses system is built for the sake of embody the student training for multiple target (basic practical ability, comprehensive design ability and innovation ability) and multilevel (basic level, progressive level and innovative level).

The content of these micro- courses focus on logistics information while logistics is a feature of our school. In this respect, we not only have a strong faculty team, but an abundant resource of information. All these concrete achievements could play a leading role in this area.

In response to the logistics information characteristics, the information technology is used to optimize logistics management process and efficiency. By constructing a diversified practice teaching system as the sake of meet the needs of society, students' practical ability of innovation will be enhanced, and modern information technology logistics personnel will be trained.

\section{Conclusion}

Training for talents of logistic information is focus on the combination of theory and practice and the adaptability of current economy and development. In addition, students are encouraged to master knowledge with a spirit of exploring mysteries for the sake of application and innovation. The system construction of multi-unit teaching helps to mobilize the enthusiasm of students and cultivate their innovative thinking, spirit and ability. Moreover, it also helps to enhance students' self-learning ability as well as observing, analyzing and problem-solving abilities, and output more professional, more innovative logistics information talents in logistics field.

\section{Acknowledgment}

This paper is supported by Funding project for Beijing Wuzi University, Yunhe scholars program(00610303/007); and funding project for Beijing Wuzi University Management science and engineering Professional group of construction projects.(No.PXM2015_014214_000039); and 2015 teaching reform project of Beijing Wuzi University (A-3). 


\section{References}

[1] Liang Wen, Ye Chunsen, $\mathrm{Wu}$ haihui. The engineering educational exploration of cultivate innovative personnel[J], logistics engineering and management, 2014, (4)

[2] Liu yaofei. Diversified practical teaching pattern design for economy and management specialty $[\mathrm{J}]$, higher education research of Heilongjiang province, 2014, (4)

[3] Lin Zhaohua, Zhen Yan, Cai X. Analysis of training mode for logistics engineering application talents [J] Logistics technology, 2013, (3)

[4] Hu xiaomin. The construction of practical teaching system of application technology university [J] Research and exploration of laboratory, 2015, (6)

[5] Wu Zhonghe, Ma Changsong, Li Junsong. Research of the diversified logistics practice teaching mode reform based on the promotion of "four abilities" [J] logistics technology, 2015, (3)

[6] Liu Dan. Study on the practice teaching system construction of logistics management major at undergraduate level [J] logistics engineering and management, 2011, (7) 